\title{
Use of systemic thrombolytic therapy in patients with non-traumatic cardiac arrest: A systematic review and meta-analysis
}

\author{
Daniel Cordoba MD, Eneko Larumbe PhD, Brittany N. Rosales MD, Kenneth Nugent MD
}

\begin{abstract}
Objective: To better delineate the benefits and risks of systemic thrombolytic therapy in patients with cardiac arrest from non-traumatic etiologies.

Data sources: MEDLINE, EMBASE, and SCOPUS were systematically searched up to November of 2017.

Study Selection: All retrospective and prospective studies in which systemic thrombolytic therapy was used during the sequence of cardiopulmonary resuscitation (CPR) or shortly after achieving return of spontaneous circulation (ROSC) were included.

Data extraction: The following variable results were extracted from intervention and control groups if available: rate of ROSC, survival after 24 hours, survival at discharge, neurological performance at 6 months based on a favorable Cerebral Performance Categories Scale (1 or 2) and major bleeding events.

Data Synthesis: Eight retrospective studies and 6 prospective studies were included in the qualitative analysis. Research synthesis was conducted when at least 4 studies were available for an outcome, which limited the analysis of major bleeding events and neurologic outcomes. Benefit of thrombolytic therapy in survival to discharge showed a moderate beneficial effect $(O R=2.79,2.11-3.69)$ in the retrospective study analysis while in the prospective study analysis no statistically significant benefit was found $(O R=1.27,0.77-2.10)$. Benefit of thrombolysis in the rate of ROSC was not statistically significant in the prospective analysis (OR $=1.59,0.92$ $2.76, p=0.138)$ as well as survival at 24 hours (OR = 1.17, 0.72-1.71).

Conclusions: The widespread use of thrombolytics in patients with non-traumatic cardiac arrest does not seem to improve major outcomes, including survival to discharge. However, the modest benefit found in the retrospective study analysis suggests a subgroup of patients that may benefit from this therapy.
\end{abstract}

Keywords: Thrombolytic therapy, cardiac arrest, advanced cardiac life support, cardiopulmonary resuscitation, tissue plasminogen activator

\section{INTRODUCTION}

Although there are multiple causes of non-traumatic cardiac arrest (CA), pulmonary thromboembolism (PE) and acute coronary syndromes (ACS) explain more than

Corresponding author: Kenneth Nugent

Contact Information: Kenneth.nugent@ttuhsc.edu

DOI: $10.12746 /$ swrccc.v7i28.538
$70 \%$ of the cases based on published autopsy series and post cardiacarrest coronary angiogram reports. ${ }^{1,2} \operatorname{In} 1974$, Renkes-Hegendorfer and Hermann reported the first patient treated with thrombolytics during CPR in a patient with PE diagnosed after a Cesarean section. ${ }^{3}$ Cardiac arrest continues to have a very poor prognosis with inhospital survival rates ranging from 10.9 to $30 \% .{ }^{4,5}$ Furthermore, out-of-hospital cardiac arrests usually have worse outcomes, with survival rates below $3 \%$, which makes the development of innovative treatment strategies necessary. ${ }^{6}$ 
The use of systemic fibrinolytic therapy (FT) during CA has two mechanisms of action that explain the logic of its use. First, the thrombolytic agent addresses the underlying potential cause of the majority of arrests (coronary or pulmonary arterial thrombosis). Second, thrombolytic therapy seems to enhance microcirculatory reperfusion by decreasing blood viscosity, thereby improving blood flow in the microcirculation. ${ }^{7}$ During and after cardiac arrest, there is a "no-reflow" phenomenon, in which the presence of diffuse/systemic micro thrombosis (driven by the slow and limited blood flow to small vascular beds) restricts the reperfusion of vital organs (especially the brain) after return of spontaneous circulation (ROSC) has occurred, explaining the poor neurologic outcomes of many patients. ${ }^{8-10}$ Additionally, there is a potential pro-thrombotic state after achieving spontaneous circulation driven by diffuse endothelial injury and subsequent abnormal fibrinolytic activity that exacerbates this process. ${ }^{11,12}$ Multiple studies conducted in animals have shown evidence for these events. ${ }^{13-15}$

Different case series have shown variable incidences of CA as the presentation of PE (from 5 to $20 \%$ ); nonetheless, there seems to be consistency in the fatality of PE causing CA (mortality exceeds $60 \%$ ). ${ }^{16-18}$ Fibrinolytic therapy in patients with $\mathrm{PE}$ and haemodynamic instability has shown mortality benefit (from $19 \%$ to $9 \%)^{8}$ The European Society of Cardiology guidelines of 2014 and the American Heart Association (AHA) guidelines of 2011 recommend the use of FT in this group of patients. ${ }^{16,17}$ The use of thrombolytic therapy has demonstrated a time dependent morbidity and mortality benefit in patients with ST segment elevation myocardial infarctions (STEMI) when used within 12 hours of symptom onset. ${ }^{19}$ For this reason, the AHA 2013 guidelines recommend its use in select patients with anticipated delay (above 120 minutes) in performance of primary percutaneous intervention. ${ }^{20}$ No benefit has been found from the use of thrombolytic therapy in patients with acute coronary syndromes without ST segment elevation. ${ }^{21,22}$ Advanced Cardiac Life Support (ACLS) guidelines do not recommend the use of systemic thrombolysis in cardiac arrest. ${ }^{23}$

In $2005 \mathrm{Xin} \mathrm{Li}$, et al. published a meta-analysis on this topic. ${ }^{24}$ Since then, multiple prospective and retrospective studies have been published, making a new systematic review and meta-analysis necessary.

\section{Methods}

\section{SEARCH STRATEGY}

A systematic review of literature was conducted in accordance with the recommended criteria provided by the Preferred Reporting Items for Systematic Reviews and Meta-Analyses (PRISMA). ${ }^{25,26}$ All available papers published up to November 2017 were identified in the MEDLINE, EMBASE, and SCOPUS databases. Selected keywords for the search were based on MeSH and EMTREE terminology in which "Heart Arrest" and "Thrombolytic therapy" were used initially to guide the search; then, further keyword combinations were applied using the following terms: "Advanced Cardiac Life Support", "Tissue Plasminogen Activator", "Tenecteplase", "Rateplase", "Streptokinase", and "Urokinase". The search was limited so that certain publications, like reviews, guidelines, letters, individual case reports, and editorials, were excluded; the search was limited to publications in humans and in English or Spanish. In addition, references cited by relevant papers were manually searched.

\section{ELIGIBILITY CRITERIA}

All retrospective and prospective studies in which systemic thrombolytic therapy was used during the sequence of cardiopulmonary resuscitation (CPR) or shortly (3 hours) after achieving ROSC were included. Studies including thrombolytic strategies other than systemic thrombolysis (e.g., catheter guided or ultrasound accelerated thrombolysis) were excluded. Publications in which thrombolytic therapy was used before cardiac arrest were also excluded.

\section{Study SELECTION}

Potentially relevant articles were selected by (1) screening the titles; (2) screening the abstracts; and (3) if abstracts did not provide sufficient data, the entire article was retrieved and screened to determine whether 


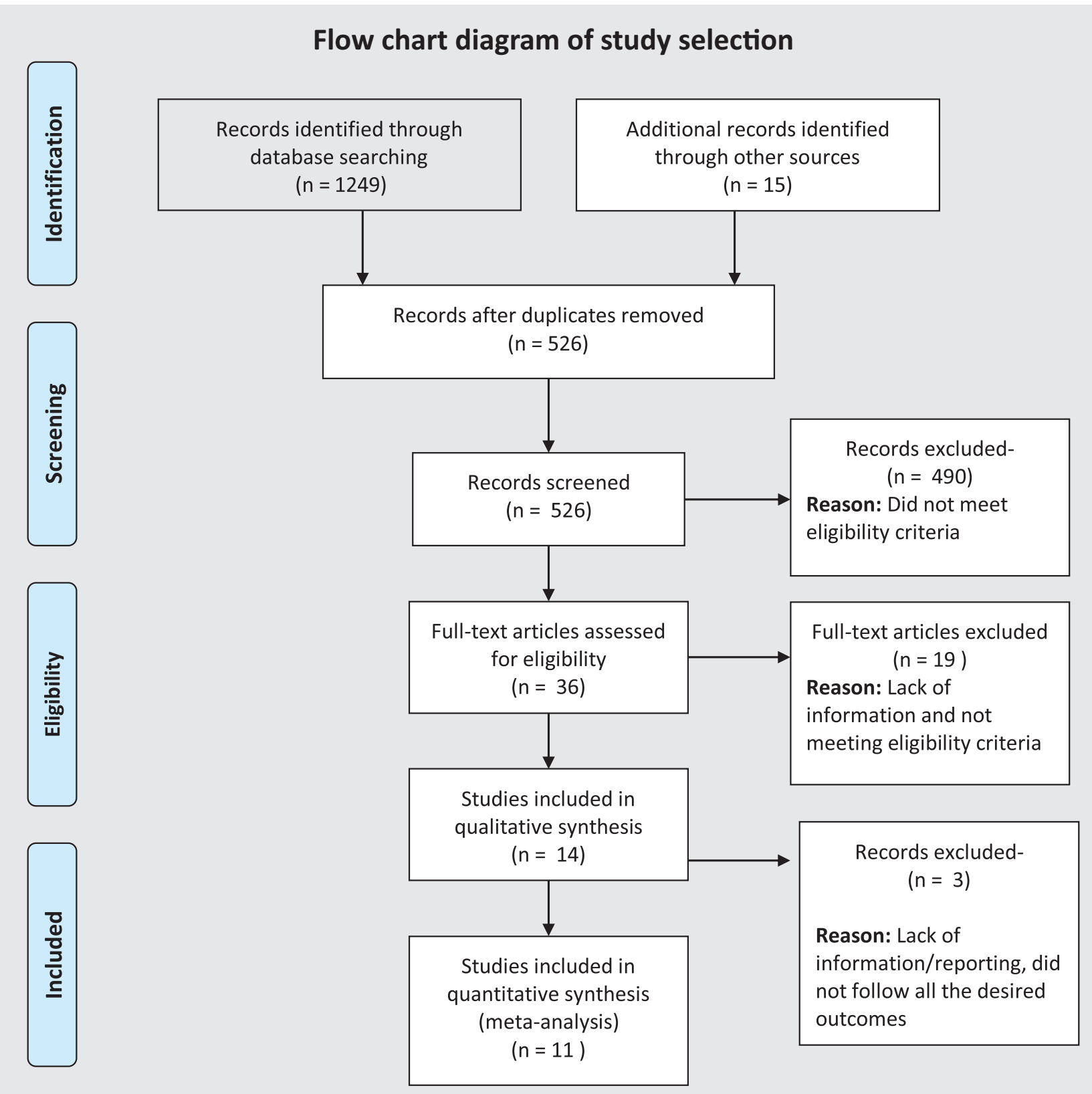

Figure 1. Literature search strategy.

it was in accordance with the eligibility criteria described above. The search results are detailed in Figure 1.

\section{DATA COLLECTION PROCESS}

The following qualitative and quantitative information was extracted from each included study: authors; publication year; baseline population characteristics; intervention and control procedures; study duration; and sample size per group. The following variable results were extracted from intervention and control groups if available: rate of ROSC, survival after 24 hours, survival at discharge, good neurological performance at 6 months based on a favorable Cerebral 
Performance Categories Scale (1 or 2), and major bleeding events. Major bleeding events are defined as any intracranial bleeding complications, bleeding events requiring transfusion support or surgical intervention, or bleeding within in a third space cavity or a solid organ.

\section{ASSESSMENT OF RISK OF BIAS}

Two reviewers ascertained individual study information as part of the quality control process. The prospective studies were assessed based on the Cochrane collaboration tool. ${ }^{27}$ Two authors performed the quality assessment independently, and their findings were compared until consensus was achieved. Six domains were reviewed and scored as -1 for high risk, 0 for unclear risk, and +1 for low risk. Scores were summed with a possible range of scores of -6 to 6 . Detailed scoring for each domain on each study is provided in Supplementary Table 1. For retrospective studies we used the Newcastle-Ottawa Quality Assessment Form for Cohort Studies which assesses basic characteristics regarding selection, comparability, and outcome domains. ${ }^{28}$ Study quality was characterized as good, fair, or poor based on AHRQ standards. Detailed assessment of each retrospective study is provided in Supplementary Table 2.

\section{Statistical anALYSIS}

Two different sets of data were collected for retrospective and prospective studies. Research synthesis was conducted when at least 4 studies were available for an outcome. From the set of retrospective studies only survival at discharge met the criteria. From the set of prospective studies, rate of ROSC, survival after 24 hours, and survival at discharge were included in the research synthesis. The random effects Mantel-Haenszel method was used to weight the studies and estimate the pooled odds ratios (OR) and $95 \%$ confidence intervals $(\mathrm{Cl})$. When using the Mantel-Haenszel method, we considered sample size and event rates. We chose odds ratios (OR) as effect measures owing to the small prevalence rates shown in some studies. Since at least one study presented a zero cell, the standard correction of 0.5 was used to perform the computation. Heterogeneity was assessed using Breslow-Day test for the odds ratios and $\mathrm{I}^{2}$ statistic. Interpretation of variation attributable to heterogeneity was based on the suggested adjectives of low for $\mathrm{I}^{2}$ values between $25 \%-50 \%$, moderate for $50 \%-75 \%$, and high for $\geq 75 \% .^{29}$ Statistical analysis was performed on Stata 13.1, and forest plots were done using $\mathrm{R}$.

\section{Analysis of PUBLICATION BIAS}

We assessed publication bias by visual inspection of asymmetry in funnel plots. ${ }^{30}$ We also carried out Begg and Mazumdar adjusted rank correlation test, and Egger regression asymmetry test for publication bias. $^{31}$

\section{RESULTS}

\section{RETROSPECTIVE STUDIES}

Eight studies were included in the qualitative analysis; their general characteristics are summarized in Table $1 .{ }^{32-39}$

The data synthesis of five retrospective studies, including data on survival at discharge, showed very low heterogeneity $\left(\mathrm{I}^{2}=0 \%, \mathrm{p}=0.528\right)$ and the funnel plot inspection showed a symmetric distribution of the studies (Figure not shown). Begg's test was not statistically significant $(p=0.806)$ and Egger's test showed no statistically significant coefficient for bias $(p=0.741)$. The pooled estimate for the five retrospective studies determined a moderate $(\mathrm{OR}=2.79,95 \%$ $\mathrm{Cl}=2.11-3.69)$ beneficial effect of thrombolytic therapy during CPR on survival at discharge (Figure 2).

Most of the studies included patients with established PE or myocardial infarction. Lederer and Renard included patients with out-of-hospital CA without a clear etiology. ${ }^{34,35}$ In general, most of the studies reported benefit from thrombolytic therapy in the majority of outcomes. Renard, et al. included a significant control group which allowed a multivariate analysis based on a propensity score in which a statistically significant difference in survival at discharge, favoring the intervention group, was still present in 
Table 1. Summary of retrospective studies

\begin{tabular}{|c|c|c|c|c|}
\hline Study & Participants & Design & $\begin{array}{l}\text { Thrombolytic } \\
\text { therapy }\end{array}$ & Findings \\
\hline $\begin{array}{l}\text { Van Campen } \\
1994[32]\end{array}$ & $\begin{array}{l}69 \text { patients ( } 33 \text { in the } \\
\text { IG), prolonged CPR } \\
\text { (over } 20 \text { minutes) }\end{array}$ & $\begin{array}{l}\text { Out of hospital } \\
\text { CA (patients with } \\
\text { presumptive MI) }\end{array}$ & $\begin{array}{l}\text { Type of medication and } \\
\text { regimen not specified, } \\
\text { given during or shortly } \\
\text { after ROSC }\end{array}$ & $\begin{array}{l}\text { Increased } 24 \mathrm{~h} \text { survival and discharge } \\
\text { survival on IG }\end{array}$ \\
\hline $\begin{array}{l}\text { Schreiber } \\
2002[39]\end{array}$ & $\begin{array}{l}157 \text { patients ( } 42 \text { in } \\
\text { the IG) with VF-CA, } \\
\text { short CPR (less than } 4 \\
\text { minutes) }\end{array}$ & $\begin{array}{l}\text { In and out of hospital } \\
\text { CA with diagnosis of } \\
\text { STEMI, only included } \\
\text { patients that survived } \\
\text { after first } 24 \mathrm{~h}\end{array}$ & $\begin{array}{l}\text { Alteplase } 100 \mathrm{mg} \text { in } \\
\text { infusion given after } \\
\text { ROSC }\end{array}$ & $\begin{array}{l}\text { Increased survival at } 6 \text { months in IG, } \\
\text { better neurologic outcome (CPC 1-2) } \\
\text { on IG at } 6 \text { months }\end{array}$ \\
\hline $\begin{array}{l}\text { Ruiz-Bailen } \\
\text { 2001[33] }\end{array}$ & $\begin{array}{l}303 \text { patients ( } 67 \text { in the } \\
\text { IG), subgroup of the } \\
\text { ARIAM study }\end{array}$ & $\begin{array}{l}\text { In-hospital CA } \\
\text { (patients with } \\
\text { presumptive MI) }\end{array}$ & $\begin{array}{l}\text { SK in 3\%, alteplase } \\
\text { infusion in } 36 \% \text {, } \\
\text { alteplase in double } \\
\text { bolus regimen in } 28 \% \text {, } \\
\text { other agents in } 3 \% \text {. } \\
\text { Given after ROSC }\end{array}$ & $\begin{array}{l}\text { Increased discharge survival in IG, } \\
\text { non-significant increase in major } \\
\text { bleeding events in IG }\end{array}$ \\
\hline $\begin{array}{l}\text { Lederer } \\
2001[34]\end{array}$ & $\begin{array}{l}325 \text { patients }(108 \text { in } \\
\text { the } I G)\end{array}$ & $\begin{array}{l}\text { Out of hospital } \\
\text { CA (undetermined } \\
\text { medical cause) }\end{array}$ & $\begin{array}{l}\text { Alteplase given } \\
\text { during CPR (Neuhaus } \\
\text { regimen-1) }\end{array}$ & $\begin{array}{l}\text { Increased rate of ROSC, } 24 \mathrm{~h} \text { survival } \\
\text { and discharge survival in IG } \\
\text { Rate of ROSC of } 70.4 \% \text { in the IG vs } \\
51 \% \text { in controls (p } 0.001 \text { ). } 24 \mathrm{~h} \text { survival } \\
\text { of } 48.1 \% \text { in IG vs } 32.9 \% \text { in CG (p } \\
0.003 \text { ). Survival to discharge of } 25 \% \\
\text { in IG vs } 15.3 \% \text { in CG (p } 0.048 \text { ) }\end{array}$ \\
\hline $\begin{array}{l}\text { Kurkciyan } \\
2003[38]\end{array}$ & $\begin{array}{l}265 \text { patients }(132 \text { in } \\
\text { the IG) }\end{array}$ & $\begin{array}{l}\text { Out of hospital CA } \\
\text { (STEMI diagnosed } \\
\text { after ROSC), patients } \\
\text { treated with PCI were } \\
\text { excluded }\end{array}$ & $\begin{array}{l}\text { Alteplase (Neuhaus } \\
\text { regimen) after ROSC }\end{array}$ & $\begin{array}{l}\text { Increased } 6 \mathrm{~m} \text { survival in IG, better } \\
\text { neurologic outcome (CPC 1-2) on IG } \\
\text { at } 6 \text { months }\end{array}$ \\
\hline $\begin{array}{l}\text { Renard } \\
2011[35]\end{array}$ & $\begin{array}{l}1261 \text { patients }(107 \text { in } \\
\text { the IG), propensity } \\
\text { score matching }\end{array}$ & $\begin{array}{l}\text { Out of hospital } \\
\text { CA (undetermined } \\
\text { medical cause) }\end{array}$ & $\begin{array}{l}\text { Alteplase (50mg bolus) } \\
\text { or tenecteplase (100UI/ } \\
\mathrm{kg} \text { in single bolus). } \\
\text { Given during CPR }\end{array}$ & $\begin{array}{l}\text { Increased discharge survival in IG } \\
\text { (significant difference in patients } \\
\text { with rhythms not amenable of } \\
\text { defibrillation) }\end{array}$ \\
\hline $\begin{array}{l}\text { Janata } \\
2003[36]\end{array}$ & $\begin{array}{l}66 \text { patients ( } 36 \text { in the } \\
\text { IG) }\end{array}$ & $\begin{array}{l}\text { In and out hospital } \\
\text { CA (confirmed PE } \\
\text { before or after CA) }\end{array}$ & $\begin{array}{l}\text { Alteplase bolus } \\
\text { (weight based, up to } \\
100 \mathrm{mg} \text { ) }\end{array}$ & $\begin{array}{l}\text { 24-hour survival } 53 \% \text { in the IG vs } 23 \% \\
\text { in the control group ( } 0.01 \text { ). ROSC } \\
\text { and survival to discharge favored IG } \\
\text { (not statistically significant). Bleeding } \\
\text { events more common in IG (not } \\
\text { statistically significant). }\end{array}$ \\
\hline $\begin{array}{l}\text { Kurkciyan } \\
2000[37]\end{array}$ & $\begin{array}{l}42 \text { patients ( } 21 \text { in the } \\
\text { IG) }\end{array}$ & $\begin{array}{l}\text { In and out of hospital } \\
\text { CA (with confirmed } \\
\text { PE) }\end{array}$ & $\begin{array}{l}\text { Alteplase (Neuhaus } \\
\text { regimen or } 2 \text { separeted } \\
\text { boluses of } 50 \mathrm{mg} \text { ) }\end{array}$ & $\begin{array}{l}\text { ROSC incidence of } 81 \% \text { in } \\
\text { intervention group vs } 43 \% \text { in the } \\
\text { control group (p } 0.03 \text { ). Survival at } 6 \\
\text { months was better in IG. }\end{array}$ \\
\hline
\end{tabular}

CA: Cardiac Arrest; IG: Intervention group; CG: Control Group; MI: Myocardial Infarction; CPR: Cardiopulmonary resuscitation; VF: Ventricular Fibrillation; CPC: Cerebral Performance Category; SK: Streptokinase; ROSC: Return of Spontaneous Circulation; Neuhaus Regimen: Alteplase given as 15mg bolus followed by 90mg in 90 minutes at 2 different infusion rates; PCI: Primary Coronary Intervention; PE: Pulmonary Embolism; PEA: Pulseless Electrical Activity, $24 \mathrm{~h}: 24$ hours. 


\begin{tabular}{|c|c|c|c|c|c|}
\hline Studies & Estimate $195 \%$ & C.I.) & $\mathrm{Ev} / \operatorname{Tr} \mathrm{t}$ & Ev/Ctrl & Weight $(\%)$ \\
\hline Ruiz-Bailen et al. 2001[33] & $3.93(2.00$ & $7.73)$ & $55 / 67$ & $127 / 236$ & 17.14 \\
\hline Janata et al. 2003 [36] & $3.38 \quad(0.65$, & $17.68)$ & $7 / 36$ & $2 / 30$ & 2.85 \\
\hline Van Campen et al. 1994 [32] & $3.08 \quad(1.15$ & $8.23)$ & $20 / 33$ & $12 / 36$ & 8.07 \\
\hline Renard et al. 2011 [35] & $2.95 \quad(1.97$ & $4.42)$ & $51 / 107$ & $272 / 1154$ & 48.07 \\
\hline Lederer et al. 2001 [34] & $1.85 \quad(1.04$, & $3.27)$ & $27 / 108$ & $33 / 216$ & 23.87 \\
\hline Overall $\left(I^{2}=0 \%, P=0.53\right)$ & $2.79(2.11$ & $3.69)$ & $160 / 351$ & $446 / 1672$ & 100 \\
\hline
\end{tabular}

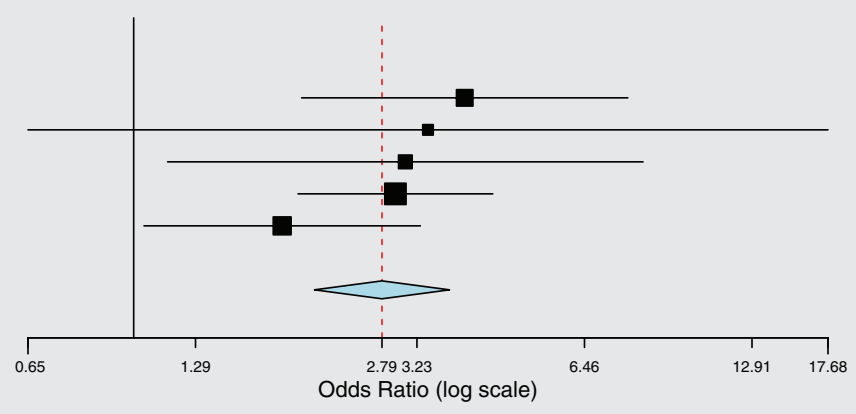

Figure 2. Odds ratio for survival at discharge in retrospective studies.

the matched analysis. ${ }^{35}$ This study also showed a significant difference in survival at discharge in the subgroup of patients who were not defibrillated during CA (48.8\% in the intervention group vs $18.2 \%$ in the control group for a OR of $3.61,95 \% \mathrm{Cl}=1.88-6.96$ ).

There were significant differences in definitions and reporting major bleeding complications and neurologic outcomes which prevented statistical analysis of these outcomes in the combined pool. Van Campen reported similar incidences of death by bleeding complications in both groups (despite prolonged cardiopulmonary resuscitation defined as more than 20 minutes); neurologic complications were similar in both groups (defined as coma, strokes, seizures or death secondary to neurological complication). ${ }^{32}$ Lederer, et al. found similar bleeding complications in his deceased patients at autopsy. ${ }^{34}$ Janata and Kurkciyan reported an increased rate of major bleeding complications in their intervention groups, although the difference was not statistically significant. ${ }^{36,37}$ Kurkciyan's study did not find any significant association between major bleeding events and duration of cardiopulmonary resuscitation (CPR) regardless of thrombolytic administration. In Ruiz-Bailen study there were no statistically significant differences in major bleeding complications between the intervention and control groups with a statistically significant difference in the incidence of anoxic encephalopathy in the intervention group. ${ }^{33}$ Kurkciyan and Schreider reported better neurologic outcomes in the intervention groups at 6 months using the cerebral performance category (CPC) scale; in both studies the results were statistically significant. ${ }^{38,39}$

\section{Prospective studies}

Six studies were included in the qualitative analysis; their general characteristics are summarized in Table $2^{40-46}$ Most of the studies had high mortality rates, regardless of the intervention, with low survival rates at discharge, which limited the reporting of neurologic outcomes and bleeding events. All the studies were conducted in patients with CA in an out-of-hospital setting with no established etiology of the arrest.

Five prospective studies were suitable for a research synthesis on survival at 24 hours, and the data presented low heterogeneity $\left(I^{2}=46 \%, p=0.113\right)$. Although the funnel plot (Figure not shown showed that the study by Bozeman was out of confidence limits, neither Begg's nor Egger's tests found statistically significant bias. ${ }^{45}$ However, the pooled estimate showed no statistically significant effect of thrombolytic therapy on survival at 24 hours $(\mathrm{OR}=1.17,95 \% \mathrm{Cl}=0.72-1.71)$ (Figure 3$)$.

Six prospective studies were included in the research synthesis on survival at discharge, and the data presented low heterogeneity $\left(I^{2}=50 \%, p=0.077\right)$. Similar to the outcomes on survival at 24 hours, the funnel plot (Figure not shown) showed that the study by Bozeman was out of confidence limits, but neither Begg's nor Egger's tests found statistically significant bias. ${ }^{45}$ Similarly, the pooled estimate of the six studies showed no statistically significant effect of thrombolytic therapy on survival at discharge $(\mathrm{OR}=1.27,95 \% \mathrm{Cl}=$ 0.77-2.10) (Figure 4).

Five prospective studies were considered for research synthesis of the rate of ROSC. The data 
Table 2. Summary of prospective studies

\begin{tabular}{|c|c|c|c|c|}
\hline Study & Participants & Design & Thrombolytic therapy & Findings \\
\hline $\begin{array}{l}\text { Bottiger } \\
2001[40]\end{array}$ & $\begin{array}{l}90 \text { patients ( } 40 \text { in the } \\
\mathrm{IG} \text { ), nonrandomized }\end{array}$ & $\begin{array}{l}\text { Out of hospital } \\
\text { (undetermined } \\
\text { medical cause), } \\
\text { observational }\end{array}$ & $\begin{array}{l}\text { Tenecteplase } 50 \mathrm{mg} \\
\text { bolus during CPR, } \\
\text { repeated after } 15 \\
\text { minutes if no ROSC }\end{array}$ & $\begin{array}{l}\text { Increased ROSC, } 24 \mathrm{~h} \\
\text { survival and discharge } \\
\text { survival in IG. Non- } \\
\text { significant increase in } \\
\text { major bleeding events in IG }\end{array}$ \\
\hline $\begin{array}{l}\text { Bottiger } \\
2008 \text { (TROICA } \\
\text { study) [41] }\end{array}$ & $\begin{array}{l}1050 \text { patients }(525 \text { in } \\
\text { the IG) }\end{array}$ & $\begin{array}{l}\text { Out of hospital } \\
\text { (undetermined } \\
\text { medical cause), } \\
\text { randomized }\end{array}$ & $\begin{array}{l}\text { Tenecteplase in one } \\
\text { bolus (weight based) } \\
\text { during CPR }\end{array}$ & $\begin{array}{l}\text { No significant difference } \\
\text { in ROSC, } 24 \mathrm{~h} \text { survival, } \\
\text { discharge survival and } \\
\text { favorable CPC (1-2) } \\
\text { at } 6 \text { months. Increased } \\
\text { intracranial hemorrhage in } \\
\text { IG. Stopped after futility } \\
\text { analysis }\end{array}$ \\
\hline $\begin{array}{l}\text { Abu-Laban } \\
2002[42]\end{array}$ & $\begin{array}{l}233 \text { patients ( } 117 \text { in the } \\
\text { IG), only patients with } \\
\text { PEA rhythm during } \\
\text { CA. Autopsies ( } 18 \% \\
\text { patients) revealed } \mathrm{MI} \text { in } \\
21 \% \text { and } \mathrm{PE} \text { in } 2.4 \%\end{array}$ & $\begin{array}{l}\text { Out of hospital } \\
\text { (undetermined } \\
\text { medical cause), } \\
\text { randomized. } \\
\text { Canada }\end{array}$ & $\begin{array}{l}\text { Alteplase } 100 \mathrm{mg} \text { in } \\
15 \text {-minute infusion }\end{array}$ & $\begin{array}{l}\text { No significant differences } \\
\text { in ROSC, } 24 \mathrm{~h} \text { survival and } \\
\text { discharge survival (only } 1 \\
\text { patient survived in the IG) }\end{array}$ \\
\hline $\begin{array}{l}\text { Stadlbauer } \\
2006 \text { [43] }\end{array}$ & $\begin{array}{l}1186 \text { patients (99 in the } \\
\text { IG) }\end{array}$ & $\begin{array}{l}\text { Out of hospital } \\
\text { CA (undetermined } \\
\text { medical cause) }\end{array}$ & $\begin{array}{l}\text { Tenecteplase or } \\
\text { rateplase (different } \\
\text { regimens) during or } \\
\text { shortly after ROSC } \\
\text { (not specified) }\end{array}$ & $\begin{array}{l}\text { Increased discharge } \\
\text { survival in IG. Statistically } \\
\text { significant in patients with } \\
\text { suspected MI }\end{array}$ \\
\hline $\begin{array}{l}\text { Bozeman } \\
2006[45]\end{array}$ & $\begin{array}{l}163 \text { patients ( } 50 \text { in the } \\
\text { IG), nonrandomized, } \\
\text { witnessed CA more } \\
\text { common in IG }\end{array}$ & $\begin{array}{l}\text { Out of hospital } \\
\text { (undetermined } \\
\text { medical cause), } \\
\text { observational }\end{array}$ & $\begin{array}{l}\text { Tenecteplase in one } \\
\text { bolus (weight based) } \\
\text { during CPR }\end{array}$ & $\begin{array}{l}\text { Increased ROSC, } 24 \mathrm{~h} \\
\text { survival and discharge } \\
\text { survival in IG (no survivors } \\
\text { in the CG) }\end{array}$ \\
\hline $\begin{array}{l}\text { Fatovich } \\
2004 \text { (TICA } \\
\text { study) [46] }\end{array}$ & $\begin{array}{l}35 \text { patients ( } 19 \text { in the } \\
\text { IG), VF more common } \\
\text { in } \mathrm{IG}, \text { PEA more } \\
\text { common in } \mathrm{CG}\end{array}$ & $\begin{array}{l}\text { Out of hospital } \\
\text { (undetermined } \\
\text { medical cause), } \\
\text { randomized. } \\
\text { Australia }\end{array}$ & $\begin{array}{l}\text { Tenecteplase } 50 \mathrm{mg} \\
\text { bolus during CPR }\end{array}$ & $\begin{array}{l}\text { Increased ROSC in IG, no } \\
\text { differences in } 24 \mathrm{~h} \text { survival } \\
\text { or discharge survival. } \\
\text { No difference in major } \\
\text { bleeding complications. }\end{array}$ \\
\hline
\end{tabular}

CA: Cardiac Arrest; IG: Intervention group; CG: Control Group; MI: Myocardial Infarction; CPR: Cardiopulmonary resuscitation; VF: Ventricular Fibrillation; CPC: Cerebral Performance Category; SK: Streptokinase; ROSC: Return of Spontaneous Circulation; PE: Pulmonary Embolism; PEA: Pulseless Electrical Activity.

presented moderate and statistically significant heterogeneity $\left(I^{2}=70 \%, p=0.01\right)$, and the funnel plot (Figure not shown) showed that the study by Fatovich was clearly out of pseudo $95 \%$ confidence limits. ${ }^{46}$ Bias was also confirmed by Begg's test ( $p=0.027$ ), although Egger's test failed to find statistically significant bias $(p=0.071)$. Even without this study, the analysis of heterogeneity did not show any improvement $\left(I^{2}=63 \%, p=0.043\right)$. The pooled estimate on the rate of ROSC was not statistically significant $(\mathrm{OR}=1.59$, 


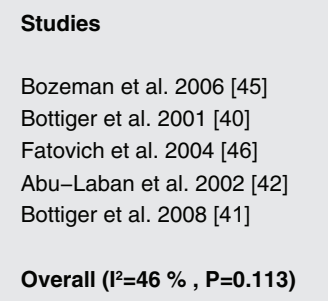

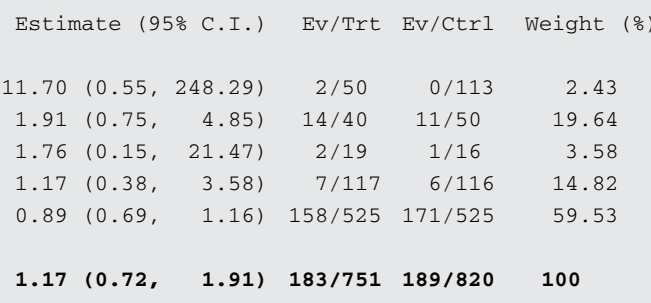

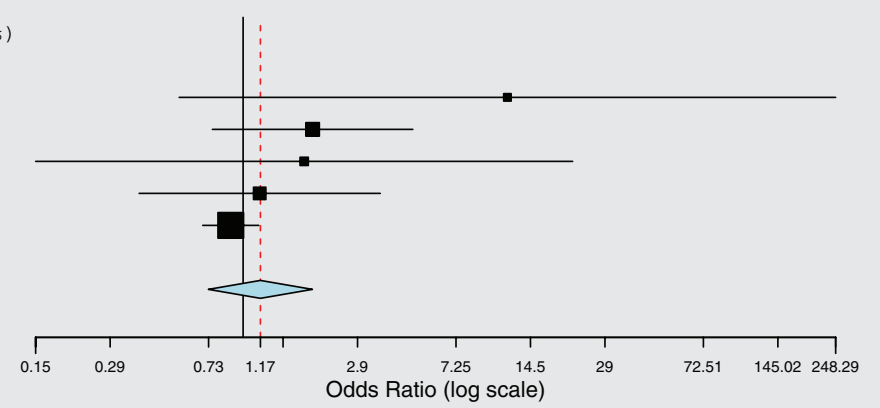

Figure 3. Odds ratio for survival at 24 hours in prospective studies.

0.92-2.76, $p=0.138$ ) (Figure 5). After removing the above-mentioned study, the effect size remained statistically insignificant $(p=0.186)$.

After reporting benefit in major outcomes in his 2001 study, Bottiger conducted a subsequent trial (TROICA) with a larger number of patients and did not find any significant difference in major outcomes except for more intracranial bleeding events in the intervention group, ending the study after a futility analysis was conducted. ${ }^{40,41}$

The study of Abu-Laban only included patients with pulseless electrical activity (PEA), although less than $3 \%$ of autopsies conducted established a diagnosis of pulmonary embolism as the underlying cause of the arrest. ${ }^{42}$ There were no significant differences in major outcomes with only one survivor at discharge. The study of Stadlbauer is a post hoc analysis of a prospective, randomized controlled trial designed to compare the use of epinephrine versus vasopressin during
ACLS. ${ }^{43,44}$ The study reported a difference, though not statistically significant, in survival to discharge (the difference was statistically significant only when patients with suspected myocardial infarction were included). Bozeman conducted a non-randomized trial that reported a statistically significant difference in the rate of ROSC favoring the intervention group. ${ }^{45}$ There were only 2 survivors, both from the FT group, from the 163 patients selected, and both had favorable neurologic outcomes at 6 months based on the CPC scale. Fatovich conducted a randomized trial with a limited sample (due to funding limitations) that reported a statistically significant difference in the rate of ROSC favoring the intervention group. ${ }^{46}$

\section{Discussion}

There is significant variability between retrospective and prospective studies. We found a statistically

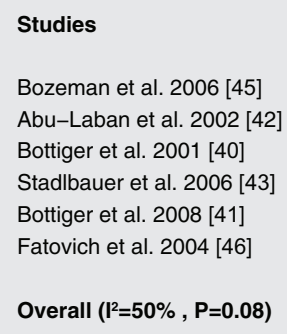

Figure 4. Odds ratio for survival at discharge in prospective studies. 


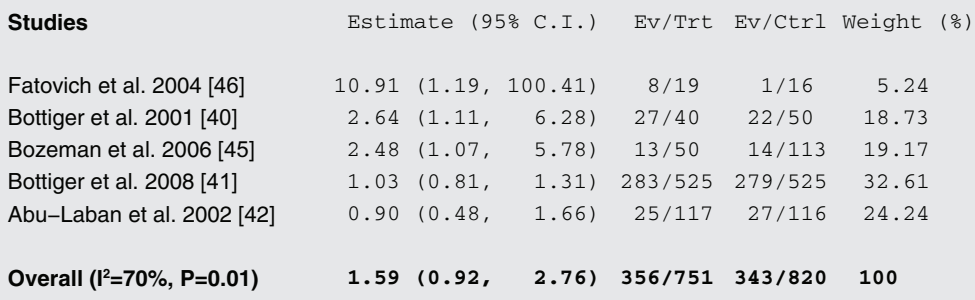

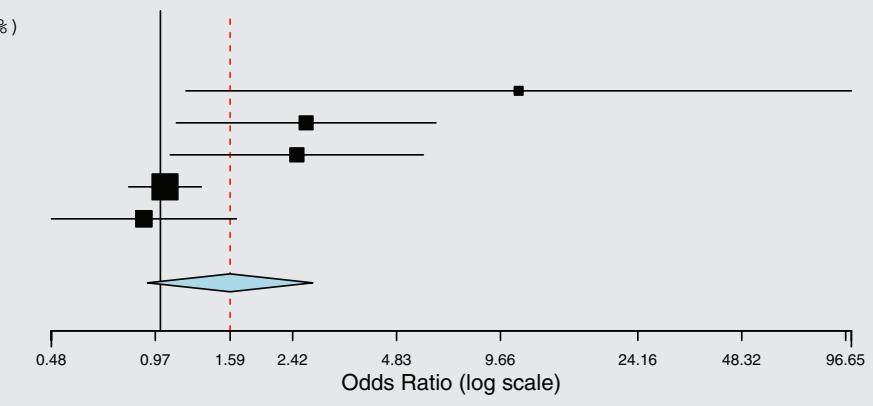

Figure 5. Odds ratio for return of spontaneous circulation in prospective studies.

significant benefit of FT in survival at discharge in our retrospective study analysis but did not find any significant benefit with the use of FT in multiple outcomes in the prospective study analysis, with the majority of the patient sample coming from the TROICA trial. Most of the retrospective studies were done in patients with established etiologies of CA (PE or STEMI), and there was significant variability between intervention and control groups (e.g., age, comorbidities, type of CA rhythm) due in part to selection bias, with only one of the studies using a propensity score for analysis. In some retrospective studies defibrillation rhythms were more prevalent; hence, the prognosis at baseline was potentially better, which may mask a real benefit from FT. There was also inconsistency in the regimens used for thrombolysis and additional medications provided during ACLS (e.g., aspirin, heparin). This variability was also found in the prospective studies.

Cardiac arrest has a very high mortality; this fact correlates better with the findings reported by most of the prospective studies compared to variable mortality rates in the retrospective studies (even in the control groups). It is important to note that because most of the patients included in the retrospective studies had myocardial infarctions (mainly STEMI) or PE their prognosis at baseline was potentially better (versus other etiologies of CA). In addition, knowing the cause of the CA makes the decision of using FT more selective, thus making this therapy potentially more effective. Compared to the retrospective studies, the prospective studies included patient with non-traumatic cardiac arrest from non-established etiologies, to the point that the study of Abu-Laban seemingly included a small percentage of patients with PE (less than $3 \%$ of the autopsies even when only patients with CA and PEA rhythms were included in the study) which could have contributed to the high mortality rates of many of these studies. $^{42}$

Based on the TROICA trial, it is unlikely that a new prospective study with similar characteristics will be conducted. Nonetheless, based on the result discrepancies noted above between retrospective and prospective cohorts, it would be useful to have new prospective studies conducted in in-hospital settings in patients diagnosed with STEMI or PE (or with very high likelihoods based on objective scoring systems) who develop CA in order to clarify the benefits and safety of this therapy in this selected group of patients.

\section{Conclusion}

Based on the prospective studies we analyzed, the widespread use of thrombolytics in patients with nontraumatic cardiac arrest does not seem to improve major outcomes, including survival to discharge, and, more significantly, it raises safety concerns (i.e., increased risk of major bleeding events). However, based on retrospective studies, there seems to be a benefit to thrombolytic use when patients are adequately selected based on their likelihood or confirmation of having a STEMI or PE as the cause of their CA. To truly determine the benefit of thrombolytic therapy in the patient population of interest, more prospective studies utilizing objective stratification strategies for these diagnoses are required to help place patients into appropriate treatment groups. 
Article citation: Cordoba D, Eneko Larumbe E, Rosales BN, Nugent K. Use of systemic thrombolytic therapy in patients with non-traumatic cardiac arrest: a systematic review and meta-analysis. The Southwest Respiratory and Critical Care Chronicles 2019;7(28):7-17

From: Department of Internal Medicine (DC, BNR, KN) and the Clinical Research Institute (EL), Texas Tech University Health Sciences Center, Lubbock, Texas

Submitted: $12 / 4 / 2018$

Accepted: 4/5/2019

Reviewer: Scott Shurmur MD

Conflicts of interest: none

This work is licensed under a Creative Commons

Attribution-ShareAlike 4.0 International License.

\section{REFERENCES}

1. Silfvast T. Cause of death in unsuccessful prehospital resuscitation. J Intern Med 1991 Apr;229(4):331-5.

2. Spaulding CM, Joly LM, Rosenberg A, et al. Immediate coronary angiography in survivors of out-of-hospital cardiac arrest. N Engl J Med 1997 Jun 5;336(23):1629-33.

3. Renkes-Hegendörfer U, Hermann K. Successful treatment of a case of fulminant massive pulmonary embolism with streptokinase. Anaesthesist 1974 Nov;23(11):500-1.

4. Ballew KA, Philbrick JT, Caven DE, et al. Predictors of survival following in-hospital cardiopulmonary resuscitation. A moving target. Arch Intern Med 1994 Nov 14;154(21): 2426-32.

5. Bedell SE, Delbanco TL, Cook EF, et al. Survival after cardiopulmonary resuscitation in the hospital. N Engl J Med 1983 Sep 8;309(10):569-76.

6. Van Walraven C, Stiell IG, Wells GA, et al. Do advanced cardiac life support drugs increase resuscitation rates from inhospital cardiac arrest? The OTAC Study Group. Ann Emerg Med 1998 Nov;32(5):544-53.

7. Böttiger BW, Martin E. Thrombolytic therapy during cardiopulmonary resuscitation and the role of coagulation activation after cardiac arrest. Curr Opin Crit Care 2001 Jun; 7(3):176-83.

8. Ames A, Wright RL, Kowada M, et al. Cerebral ischemia. II. The no-reflow phenomenon. Am J Pathol 1968 Feb; 52(2):437-53.

9. Fischer EG, Ames A, Hedley-Whyte ET, et al. Reassessment of cerebral capillary changes in acute global ischemia and their relationship to the "no-reflow phenomenon." Stroke 1977 Feb; 8(1):36-9.
10. Safar P. Cerebral resuscitation after cardiac arrest: a review. Circulation 1986 Dec; 74(6 Pt 2): IV138-153.

11. Böttiger BW, Motsch J, Böhrer H, et al. Activation of blood coagulation after cardiac arrest is not balanced adequately by activation of endogenous fibrinolysis. Circulation 1995 Nov 1;92(9):2572-8.

12. Gando $S$, Kameue T, Nanzaki S, et al. Massive fibrin formation with consecutive impairment of fibrinolysis in patients with out-of-hospital cardiac arrest. Thromb Haemost 1997 Feb; 77(2):278-82.

13. Fischer M, Böttiger BW, Popov-Cenic S, et al. Thrombolysis using plasminogen activator and heparin reduces cerebral no-reflow after resuscitation from cardiac arrest: an experimental study in the cat. Intensive Care Med 1996 Nov; 22(11):1214-23.

14. Lin SR, O'Connor MJ, Fischer HW, et al. The effect of combined dextran and streptokinase on cerebral function and blood flow after cardiac arrest: and experimental study on the dog. Invest Radiol 1978 Dec;13(6):490-8.

15. Kim YH, Park JH, Hong SH, et al. Nonproteolytic neuroprotection by human recombinant tissue plasminogen activator. Science 1999 Apr 23;284(5414):647-50.

16. Konstantinides SV, Torbicki A, Agnelli G, et al. 2014 ESC guidelines on the diagnosis and management of acute pulmonary embolism. Eur Heart J2014 Nov 14;35(43):3033-3069, 3069a-3069k.

17. Jaff MR, McMurtry MS, Archer SL, et al. Management of massive and submassive pulmonary embolism, iliofemoral deep vein thrombosis, and chronic thromboembolic pulmonary hypertension: a scientific statement from the American Heart Association. Circulation 2011 Apr 26;123(16):1788-830.

18. Bailén MR, Cuadra JA, Aguayo De Hoyos E. Thrombolysis during cardiopulmonary resuscitation in fulminant pulmonary embolism: a review. Crit Care Med 2001 Nov;29(11): 2211-9.

19. Fibrinolytic Therapy Trialists' (FTT) Collaborative (last). Indications for fibrinolytic therapy in suspected acute myocardial infarction: collaborative overview of early mortality and major morbidity results from all randomised trials of more than 1000 patients [Internet]. Centre for Reviews and Dissemination (UK); 1994. Available from: https://www.ncbi.nlm.nih. gov/books/NBK66304/

20. O'Gara PT, Kushner FG, Ascheim DD, et al. 2013 ACCF/ AHA guideline for the management of ST-elevation myocardial infarction: a report of the American College of Cardiology Foundation/American Heart Association Task Force on Practice Guidelines. JAm Coll Cardiol 2013 Jan 29;61(4):e78-140.

21. Effects of tissue plasminogen activator and a comparison of early invasive and conservative strategies in unstable angina and non-Q-wave myocardial infarction. Results of the TIMI 
IIIB Trial. Thrombolysis in Myocardial Ischemia. Circulation 1994 Apr;89(4):1545-56.

22. Anderson HV, Cannon CP, Stone PH, et al. One-year results of the Thrombolysis in Myocardial Infarction (TIMI) IIIB clinical trial. A randomized comparison of tissue-type plasminogen activator versus placebo and early invasive versus early conservative strategies in unstable angina and non-Q wave myocardial infarction. J Am Coll Cardiol 1995 Dec;26(7):1643-50.

23. Neumar RW, Shuster M, Callaway CW, et al. Part 1: Executive Summary: 2015 American Heart Association Guidelines Update for Cardiopulmonary Resuscitation and Emergency Cardiovascular Care. Circulation 2015 Nov 3;132 (18 Suppl 2):S315-367.

24. Li X, Fu Q, Jing X, et al. A meta-analysis of cardiopulmonary resuscitation with and without the administration of thrombolytic agents. Resuscitation 2006 Jul;70(1):31-6.

25. Liberati A, Altman DG, Tetzlaff J, et al. The PRISMA statement for reporting systematic reviews and meta-analyses of studies that evaluate health care interventions: explanation and elaboration. PLoS Med 2009 Jul 21;6(7):e1000100.

26. Moher D, Liberati A, Tetzlaff J, et al. Preferred reporting items for systematic reviews and meta-analyses: the PRISMA statement. PLoS Med 2009 Jul 21;6(7):e1000097.

27. Higgins JPT, Altman DG, Gøtzsche PC, et al. The Cochrane Collaboration's tool for assessing risk of bias in randomised trials. BMJ. 2011 Oct 18;343:d5928.

28. Ottawa Hospital Research Institute [Internet]. [cited 2018 May 6]. Available from: http://www.ohri.ca/programs/ clinical_epidemiology/oxford.asp

29. Higgins JPT, Thompson SG, Deeks JJ, et al. Measuring inconsistency in meta-analyses. BMJ 2003 Sep 6;327(7414): 557-60.

30. Borenstein M, Hedges LV, Higgins JPT, et al. Introduction to Meta-Analysis. John Wiley \& Sons;2011.434 p.

31. Palmer TM, Sterne JAC. Meta-Analysis in Stata: An Updated Collection from the Stata Journal, Second Edition. Second. College Station, TX: Stata Press;2015.534p.

32. Van Campen LC, Van Leeuwen GR, Verheugt FW. Safety and efficacy of thrombolysis for acute myocardial infarction in patients with prolonged out-of-hospital cardiopulmonary resuscitation. Am J Cardiol 1994 May 15;73(13):953-5.

33. Ruiz-Bailén M, Aguayo de Hoyos E, Serrano-Córcoles MC, et al. Efficacy of thrombolysis in patients with acute myocardial infarction requiring cardiopulmonary resuscitation. Intensive Care Med 2001 Jun;27(6):1050-7.
34. Lederer W, Lichtenberger C, Pechlaner C, et al. Recombinant tissue plasminogen activator during cardiopulmonary resuscitation in 108 patients with out-of-hospital cardiac arrest. Resuscitation $2001 \mathrm{Jul} ; 50(1): 71-6$.

35. Renard A, Verret C, Jost D, et al. Impact of fibrinolysis on immediate prognosis of patients with out-of-hospital cardiac arrest. J Thromb Thrombolysis 2011 Nov;32(4):405-9.

36. Janata K, Holzer M, Kürkciyan I, et al. Major bleeding complications in cardiopulmonary resuscitation: the place of thrombolytic therapy in cardiac arrest due to massive pulmonary embolism. Resuscitation 2003 Apr;57(1):49-55.

37. Kurkciyan I, Meron G, Sterz F, et al. Pulmonary embolism as a cause of cardiac arrest: presentation and outcome. Arch Intern Med 2000 May 22;160(10):1529-35.

38. Kurkciyan I, Meron G, Sterz F, et al. Major bleeding complications after cardiopulmonary resuscitation: impact of thrombolytic treatment. J Intern Me. 2003 Feb;253(2):128-35.

39. Schreiber W, Gabriel D, Sterz F, et al. Thrombolytic therapy after cardiac arrest and its effect on neurological outcome. Resuscitation. 2002 Jan;52(1):63-9.

40. Böttiger BW, Bode C, Kern S, et al. Efficacy and safety of thrombolytic therapy after initially unsuccessful cardiopulmonary resuscitation: a prospective clinical trial. Lancet Lond Engl 2001 May 19;357(9268):1583-5.

41. Böttiger BW, Arntz H-R, Chamberlain DA, et al. Thrombolysis during resuscitation for out-of-hospital cardiac arrest. N Engl J Med 2008 Dec 18;359(25):2651-62.

42. Abu-Laban RB, Christenson JM, Innes GD, et al. Tissue plasminogen activator in cardiac arrest with pulseless electrical activity. $N$ Engl $J$ Med. 2002 May 16;346(20): $1522-8$.

43. Stadlbauer KH, Krismer AC, Arntz HR, et al. Effects of thrombolysis during out-of-hospital cardiopulmonary resuscitation. Am J Cardiol 2006 Feb 1;97(3):305-8.

44. Wenzel V, Krismer AC, Arntz HR, et al. A comparison of vasopressin and epinephrine for out-of-hospital cardiopulmonary resuscitation. $N$ Engl J Med 2004 Jan 8;350(2): $105-13$.

45. Bozeman WP, Kleiner DM, Ferguson KL. Empiric tenecteplase is associated with increased return of spontaneous circulation and short term survival in cardiac arrest patients unresponsive to standard interventions. Resuscitation 2006 Jun;69(3):399-406.

46. Fatovich DM, Dobb GJ, Clugston RA. A pilot randomised trial of thrombolysis in cardiac arrest (The TICA trial). Resuscitation 2004 Jun;61(3):309-13. 